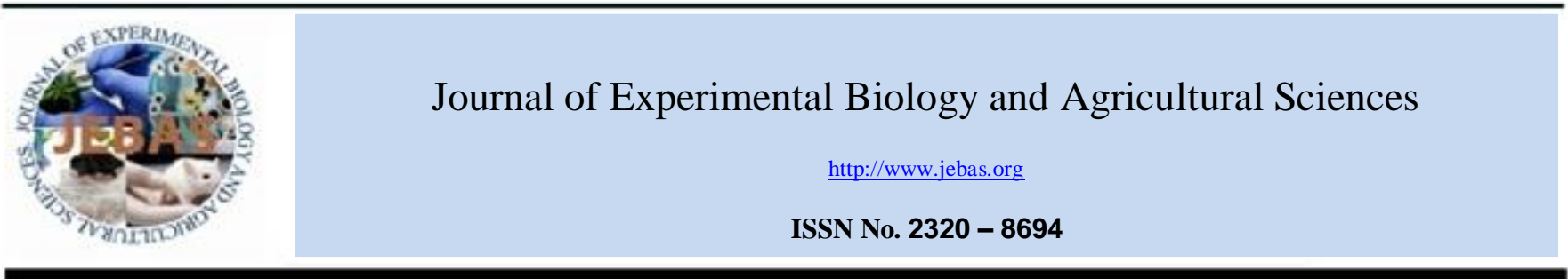

\title{
MICROSPOROGENESIS MANIPULATION BY CHA'S TO ELIMINATE EMASCULATION IN HYBRID SEED PRODUCTION OF OKRA (Albemoschus esculemtum L.)
}

\author{
Naveen N, Pallavi HM*, Satish D, Sarvamangala S Cholin, VM Ganiger, Babu AG \\ Department of Biotechnology and Crop Improvement, University of Horticulture Sciences, Bagalkot, Karnataka -587104 \\ Received - June 24, 2017; Revision - September 09, 2017; Accepted - October 04, 2017 \\ Available Online - October 31, 2017 \\ http://dx.doi.org/10.18006/2017.5(5).623.630
}

KEYWORDS
Male sterility
Pollen sterility
Microgametogensis
Pollen viability
Chemical Hybridising agents

* Corresponding author

E-mail: pallavi.hm@uhsbagalkot.edu.in (Pallavi HM)

Peer review under responsibility of Journal of Experimental Biology and Agricultural Sciences.

Production and Hosting by Horizon Publisher India [HPI] (http://www.horizonpublisherindia.in/).

All rights reserved.

\begin{abstract}
Present study was conducted to identify effective microsporogeneis and flower bud stage for application of male gametocides to induce pollen sterility in okra. Results of study revealed the association of floral bud size and stages of microsporogenesis in female parental lines. Formation of microspore from PMC is between $3 \mathrm{~mm}$ to $5 \mathrm{~mm}$ bud size. Further, it was reported that Meiosis I completed when but is under $5 \mathrm{~mm}$ and after this microgametogenesis start appearing when the bud size between $10 \mathrm{~mm}$ to $40 \mathrm{~mm}$ buds. However, pollen remains nonviable till bud reaches $45 \mathrm{~mm}$ size and attains maturity just before flower anthesis between $45 \mathrm{~mm}$ to $50 \mathrm{~mm}$ bud size. Days taken in formation of microspore to viable pollen grain are 18-20 days. Male gametocides used in the study were effective in inducing pollen sterility and vary with different stages of microsporogeneis and bud growth. Among the different treatment combinations, $45 \mathrm{~mm}$ bud size treated with malic hydrazide at $450 \mathrm{ppm}$ induced higher pollen sterility under in vitro pollen germination test $(93.40 \%)$ and this was followed by the acetocarmine (90.77\%) and ethrel @ 3000 ppm (80.68) at 45 mm bud size.
\end{abstract}

All the article published by Journal of Experimental Biology and Agricultural Sciences is licensed under a Creative Commons Attribution-NonCommercial 4.0 International License Based on a work at www.jebas.org.

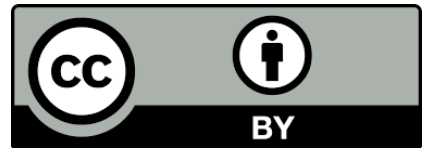




\section{Introduction}

Hybrid seed production of okra (Abelmoschus esculentum L.) has an impact on economic traits of seed production. Due to the availability of skilled labour and climatic conditions, about 29.3 $\%$ of the total okra hybrid seeds of India are produced in Karnataka (Davaluri, 2015). Presently hybrid seeds are produced using hand emasculation and pollination technique, which considered as tedious, cumbersome, expensive, laborious and time consuming process. The floral biology and structure of Okra demands continuous labour for 25 to 40 days during flowering period for emasculation followed by pollination. The process of emasculation is painful as buds are thorny and sticky due to this Child labours are majorly engaged (Davaluri, 2015). This has made a way to find an alternative technique to skip emasculation process and directly go for pollination. Hand emasculation process can be skipped if female parent is a male sterile line. Apart from elimination of tedious hand emasculation technique, male sterile line will provide more flexibility to breeding programme, facilitating quick incorporation of diverse genes for stress resistance and also reducing cost of $F_{1}$ hybrid seeds.

Male gametocides also called as CHA's are known to induce male sterility in okra (Dubey \& Singh, 1967; Deepak et al., 2007) and male gametocides will selectively kills only male gametes, spores or organs and render the treated plants to male sterile. However, no single male gametocide has reported to induce 100 per cent male sterility in okra. The effectiveness of these male gametocides depends on the stages of buds too. According to Rehm (1952) male sterility was effectively induced when plants are sprayed with 2, 4-D a week before the first flower. High levels of pollen sterility were also found in lettuce plants when immature flower buds were sprayed with ethrel (Han \& Lee, 1972). Van der Meer \& Van Bennekom (1973) also reported that foliar application of Maleic Hydrazide (MH) @ 500 ppm at bolting stage gave complete pollen sterility in cole crops. Salgare (1995) found 50 per cent male sterility by the application of MH and 2, 4- D at 100 ppm concentrations in ornamental chilli. Prakash et al. (2001) also reported that one week before flowering, spray of ethrel (400 ppm) and 2, 4- D (40 ppm) induced maximum sterility. Similarly, when Deepak et al. (2007) sprayed MH @ 200 ppm at 20+30+40 Days after sowing resulted in higher sterility $(84.33 \%)$ and this sterility percentage was followed by ethrel (1250 ppm) $(82.10 \%)$. The proper timing of the activity of enzymes during pollen development is critical for normal development of pollen. Any disturbance in the activity of callase enzyme will result in pollen sterility (Sharma \& Sharma, 2005). The effectiveness of male gametocides on pre-meiotic and post meiotic stages to ensure cent per cent artificial male sterility need to be study in Okra. Hence, the present study was formulated to identify the association of bud size with microsporogeneis growth stages to identify effective bud growth stage (bud size) for application of male gametocide to induce maximum pollen sterility in okra for skipping emasculation in commercial hybrid seed production.

\section{Materials and Methods}

The experiment was conducted at Seed Testing Laboratory, Seed Unit, Main campus, University of Horticultural Sciences, Bagalkot, Karnataka $\left(16.1635^{\circ} \mathrm{N}, 75.6172^{\circ}\right.$ E) during 2015-16. Flower buds from two different female parental of two commercial hybrids were used. Flower buds ranging from $3 \mathrm{~mm}$ (at the time of bud initiation) to $50 \mathrm{~mm}$ size (at the time anthesis) were collected and labelled as $\mathrm{B}_{1}, \mathrm{~B}_{2}, \mathrm{~B}_{3}, \mathrm{~B}_{4}, \mathrm{~B}_{5}, \mathrm{~B}_{6}, \mathrm{~B}_{7}, \mathrm{~B}_{8}, \mathrm{~B}_{9}$ and $\mathrm{B}_{10}$.

\subsection{Fixation of buds and preparation of slides:}

Meiotic studies of flower buds were studied after fixing the developmental stages. The buds of predetermined size were collected and fixed during early morning $(5.00-5.30 \mathrm{am})$ by dipping buds in corney's fixing solution (Yoneyama et al., 2013). Buds were soaked in/dipped in fixative solution for 24 hours, this was followed by the storing these buds in 70 per cent alcohol for dissection of anthers. From each fixed flower buds ten anthers were studied separately, developing PMC's were extracted by squeezing anther on glass slides.

For slide preparation, Acetocarmine (1\%) was added to PMC's and desirable spread of the chromosomes was obtained by application of pressure on the cover slip over several folds of blotting paper. Later the slides were warmed and are temporarily sealed with paraffin wax and observe under microscope. Camera lucida drawings and photomicrographs were made from temporary slide preparations. All the observed developmental phases were classified into different stages of meiosis/cell division based on the cytological observations

Further, the effect of Chemical hybridising Agents (CHA's) on different flower buds sizes was studied in-vitro (Figure 2). Flower buds of different sizes ranging from $40 \mathrm{~mm}, 45 \mathrm{~mm}$ and $50 \mathrm{~mm}$ were collected from two female parental lines. Buds size was selected based on the results of the bud size association with pollen developmental stages. The buds collected were fixed using fixative after treating with CHA's at different concentration viz., malic hydrazide (400, 450 and 500 ppm), ethrel (1000, 2000 and $3000 \mathrm{ppm})$ and 2, 4- D (10, 20 and $30 \mathrm{ppm})$ were used to soak flower buds for 12 hours. Pollen viability was assessed using acetocarmine test (Gaaliche et al., 2013) and results were confirmed in in-vitro pollen germination test on pollen germination media (Dafni \& Firmage, 2000). Anthers dissected out from treated buds by using forceps and needle to place on glass slides and a drop of acetocarmine stain was added and 
tapped gently to release the pollen grains followed by stirring with the help of needle thoroughly and then cover slip was covered on the pollen. The stained slides were heated gently and uniform pressure was applied on the edge of cover slip to flatten the anther uniformly. Edges of cover slip were sealed with wax and observed under microscope by taking minimum of five microscopic fields. In each field, number of pollen grains with red stained and unstained pollens were counted and recorded. The red stained scored as fertile and unstained pollen grains as sterile. The per cent pollen sterility was calculated using the formula

$$
\text { Pollen sterility }(\%)=\frac{\begin{array}{c}
\text { Number of unstained pollen } \\
\text { grains }
\end{array}}{\text { Total number of pollen grains }} \times 100
$$

Pollen germination medium was prepared using $\mathrm{KNO}_{3}(0.01 \%)$, $\mathrm{CaNO}_{3}(0.03 \%)$, sucrose $(20 \%)$, Boric acid $(0.01 \%)$ and $\mathrm{MgSo}_{4}$ $(0.02 \%)$. A drop of freshly prepared medium was placed on clean glass slide in circular form using camel hair brush. Pollen grains extracted from anther were smeared onto the sitting droplets of the medium and spread with brush so as to assure complete saturation of pollen grains in the media. A separate glass petri plates were taken and lined with moistened filter paper. Additional 2 to 3 droplets of water was added to maintain optimum relative humidity. The pollen grains inoculated slides were then carefully kept on moistened filter paper in petri plates covered half a way using upper petri plates and these petri plates were incubated at $30^{\circ} \mathrm{C} \pm 2{ }^{\circ} \mathrm{C}$ temperature. After 3 hours of incubation, the slides were observed under microscope for germination of pollen grains. A drop of acetocarmine was added to germinating pollen grain to document photographs. If the pollen grain germinates by producing the pollen tube was counted as fertile pollen and pollens without pollen tubes were considered as sterile pollen. The Factorial CRD observations were analyzed statistically and critical difference $(C D)$ values were calculated at 1 percent $(\mathrm{p}=$ 0.01 ) for laboratory experiments using OPISTAT software where experiment found significant. In case of non-significant effects, value of standard error of means alone was presented and tabulated.

\section{Results and Discussion}

The results of study revealed that different development stages of microsporogenesis were found to occur in $3-5 \mathrm{~mm}$ bud size and complete before bud reaching $10 \mathrm{~mm}$ size. Meiotic cell division I was completed in $3 \mathrm{~mm}$ size bud while Meiotic II of triad and tetrad were recorded (Figure 1 and table 1) in $5 \mathrm{~mm}$ and $10 \mathrm{~mm}$ size bud, respectively. Microspore undergone cell division to produced gamete was observed from $10 \mathrm{~mm}$ bud size to $45 \mathrm{~mm}$ size bud. The formation of outer layer callose deposition in pollen grain occurs from bud size of $10 \mathrm{~mm}$ to $45 \mathrm{~mm}$. The developed microspore remained nonviable till the bud size reaches $40 \mathrm{~mm}$ and did not show any red staining in acetocarmine test, this confirmed that pollen are formed but not matured. Completely

\begin{tabular}{|c|c|c|c|}
\hline \multicolumn{2}{|c|}{ Bud Size (mm) } & \multicolumn{2}{|c|}{ Developmental Stages in Microsporogenesis and microgametogenesis } \\
\hline $\mathrm{B}_{1}$ & 3 & Meiosis I & \multirow{3}{*}{$\begin{array}{l}\text { Microsporogenesis } \\
\text { PMC to Microsporocyte }\end{array}$} \\
\hline $\mathrm{B}_{2}$ & 5 & Meiosis II (Dyads) & \\
\hline $\mathrm{B}_{3}$ & 10 & Meiosis II (Tetrads) & \\
\hline $\mathrm{B}_{4}$ & 15 & Microspore formation & \multirow{8}{*}{$\begin{array}{l}\text { Microgametogenesis } \\
\text { Microspore to microgamete }\end{array}$} \\
\hline $\mathrm{B}_{5}$ & 20 & Increased size of vacuole in microspore & \\
\hline $\mathrm{B}_{6}$ & 25 & Initiation of mitosis I and deposition of callose on cell wall & \\
\hline $\mathrm{B}_{7}$ & 30 & Occurrence of mitosis I and deposition of callose on cell wall & \\
\hline $\mathrm{B}_{8}$ & 35 & $\begin{array}{l}\text { Formation of vegetative nucleus (Bicellular pollen) and deposition of } \\
\text { callose on cell wall }\end{array}$ & \\
\hline $\mathrm{B}_{9}$ & 40 & Initiation on Mitosis II of nucleus and deposition of callose on cell wall & \\
\hline $\mathrm{B} 10$ & 45 & $\begin{array}{l}\text { Formation of vegetative nucleus (Tricellular pollen) and deposition of } \\
\text { callose on cell wall }\end{array}$ & \\
\hline B11 & 50 & $\begin{array}{l}\text { Formation of vegetative nucleus (Tricellular pollen) and deposition of } \\
\text { callose on cell wall }\end{array}$ & \\
\hline
\end{tabular}

Table 1 Developmental stages of microsporogenesis in female parental lines of okra (A. esculentus)

Journal of Experimental Biology and Agriculture Science http://www.jebas.org 

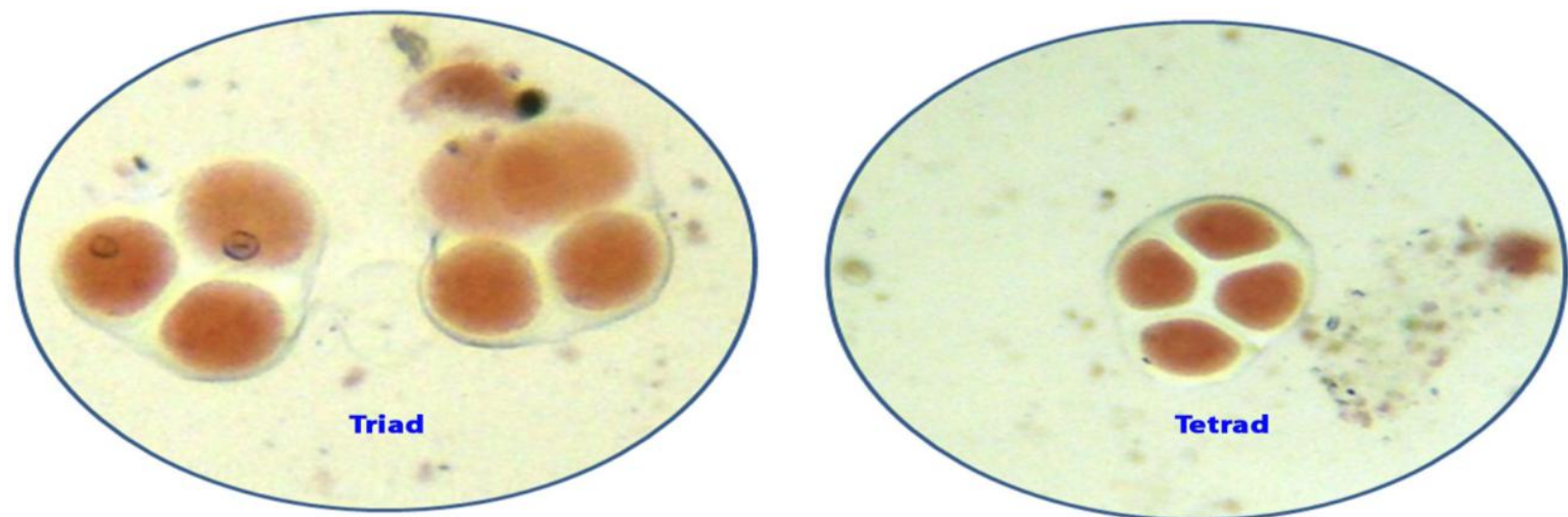

Figure 1 Triad and tetrad stage of microspore development in $3 \mathrm{~mm}$ and $5 \mathrm{~mm}$ bud size, respectively in okra

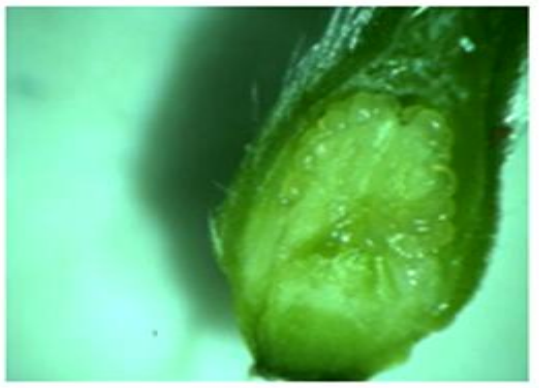

$5 \mathrm{~mm}$

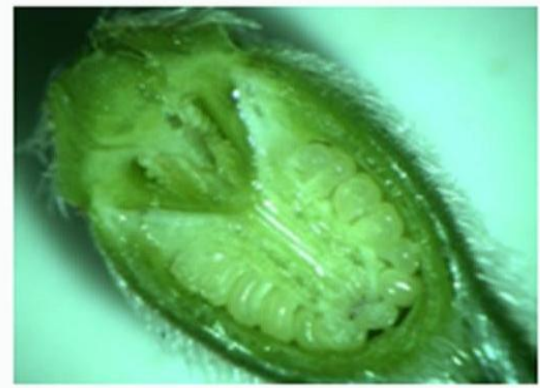

$20 \mathrm{~mm}$

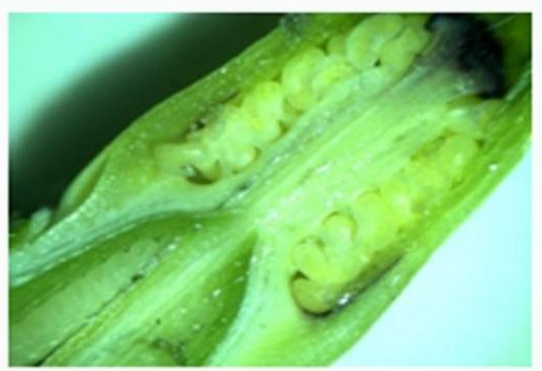

$35 \mathrm{~mm}$

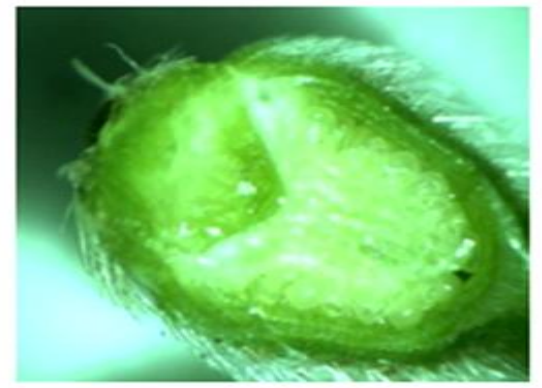

$10 \mathrm{~mm}$

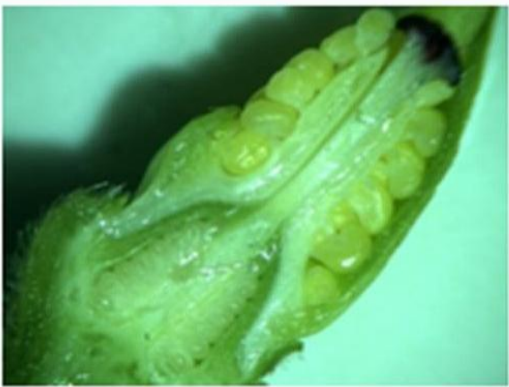

$25 \mathrm{~mm}$

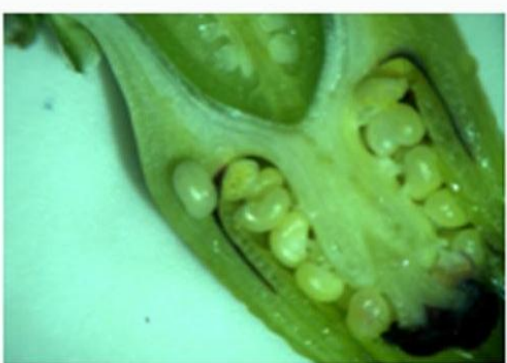

$40 \mathrm{~mm}$

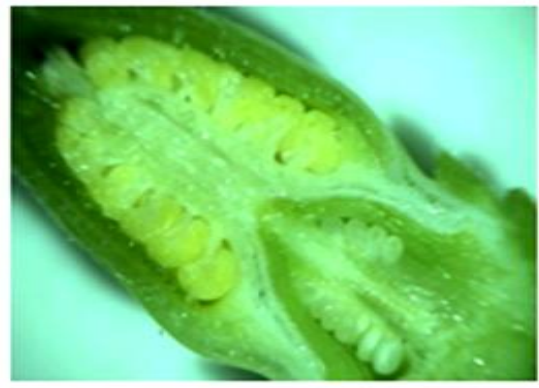

$15 \mathrm{~mm}$

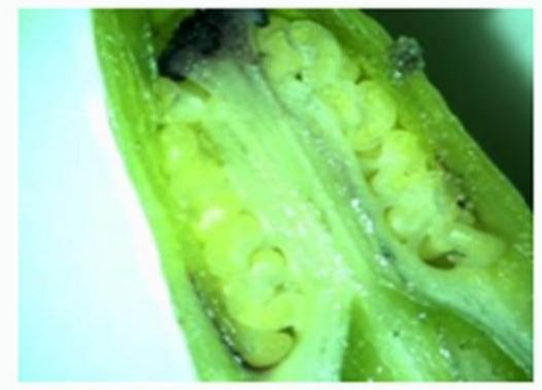

$30 \mathrm{~mm}$

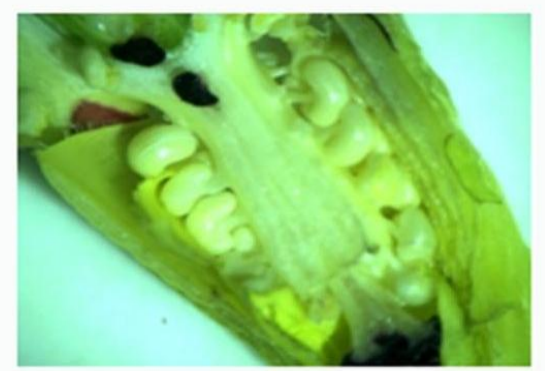

$45 \mathrm{~mm}$

Figure 2 Transverse section of stamina column as observed in different bud size of okra

Journal of Experimental Biology and Agriculture Science http://www.jebas.org 
developed pollen became viable when bud size increases more than $40 \mathrm{~mm}$. Interestingly, maximum viability is observed only one hour before anthesis (50 $\mathrm{mm}$ bud size).

The meiotic phase was seen in buds of 3 to $5 \mathrm{~mm}$ and post meiotic phases and division of nucleus to form two or three nucleus was from $10 \mathrm{~mm}$ to $40 \mathrm{~mm}$ bud siz0e. However, the fertility of the pollen was gained in $40 \mathrm{~mm}$ bud size and it was maximum at 50 $\mathrm{mm}$ (at the time anthesis).

The viability of the pollen extracted from buds less than $40 \mathrm{~mm}$ could not be assessed in acetocarmine test as pollens were nonviable. Hence, the study on CHA's for inducing pollen sterility was implemented from 40 to $50 \mathrm{~mm}$ size buds. The results obtained were tabulated and presented in table 2 and 3 . The results revealed that among different CHA's, Maleic hydrazide has induced significantly higher pollen sterility $(87.99 \%)$ and this was followed by 2, 4-D (67.58 \%) and Ethrel (66.68 \%). Lower pollen sterility was recorded in untreated control $(13.29 \%)$ at it was not statistically different that the distilled water $(13.38 \%)$. The pollen sterility has increased along with the increase in concentration in all CHA's. Flower buds treated with $500 \mathrm{ppm}$ of MH have shown higher pollen sterility $(89.76 \%$ ), which is at par the $450 \mathrm{ppm}$ of $\mathrm{MH}(89.64 \%)$. Among the different flower bud size, higher pollen sterility $(64.62 \%)$ was reported from the 45 $\mathrm{mm}$ bud and it was at par the $50 \mathrm{~mm}$ bud size $(64.58 \%)$. In three

Table 2 Effect of male gametocides on inducing pollen sterility (\%) studied under Acetocarmine test in okra (A. esculentus)

\begin{tabular}{|c|c|c|c|c|c|c|c|c|c|c|c|c|}
\hline \multirow{2}{*}{ Treatment } & \multicolumn{4}{|c|}{ Female Parent 1} & \multicolumn{4}{|c|}{ Female Parent 2} & \multicolumn{3}{|c|}{$\mathbf{T} \times \mathbf{B}$} & \multirow[b]{2}{*}{ Mean } \\
\hline & $\mathbf{B}_{1}$ & $\mathbf{B}_{2}$ & $\mathbf{B}_{\mathbf{3}}$ & Mean & $\mathbf{B}_{1}$ & $\mathbf{B}_{2}$ & $\mathbf{B}_{\mathbf{3}}$ & Mean & $\mathbf{B}_{1}$ & $\mathbf{B}_{2}$ & $\mathbf{B}_{\mathbf{3}}$ & \\
\hline $\begin{array}{c}\text { MH } \\
@ 400 \text { ppm }\end{array}$ & 79.68 & 84.71 & 89.47 & 84.62 & 79.68 & 83.25 & 89.47 & 84.13 & 79.68 & 83.98 & 89.47 & 84.37 \\
\hline $\begin{array}{c}\text { MH } \\
@ 450 \text { ppm }\end{array}$ & 89.00 & 91.11 & 90.09 & 90.07 & 88.06 & 90.44 & 89.18 & 89.23 & 88.53 & 90.77 & 89.63 & 89.64 \\
\hline $\begin{array}{c}\text { MH } \\
\text { @ 500 ppm }\end{array}$ & 88.13 & 91.18 & 90.17 & 89.83 & 87.72 & 91.18 & 90.17 & 89.69 & 87.92 & 91.18 & 90.17 & 89.76 \\
\hline $\begin{array}{c}\text { Ethrel } \\
@ 1000 \text { ppm }\end{array}$ & 53.01 & 57.58 & 60.28 & 56.96 & 54.56 & 56.00 & 58.33 & 56.30 & 53.78 & 56.79 & 59.30 & 56.62 \\
\hline $\begin{array}{c}\text { Ethrel } \\
@ 2000 \text { ppm }\end{array}$ & 54.89 & 70.67 & 74.23 & 66.60 & 49.97 & 68.95 & 74.99 & 64.64 & 52.43 & 69.81 & 74.61 & 65.62 \\
\hline $\begin{array}{c}\text { Ethrel } \\
\text { @ 3000 ppm } \\
\end{array}$ & 69.81 & 81.13 & 83.68 & 78.21 & 69.28 & 79.39 & 83.68 & 77.45 & 69.54 & 80.26 & 83.68 & 77.82 \\
\hline $\begin{array}{c}\text { 2, 4-D } \\
@ 10 \mathrm{ppm} \\
\end{array}$ & 52.45 & 52.40 & 53.73 & 52.86 & 50.79 & 56.58 & 62.26 & 56.54 & 51.62 & 54.49 & 57.99 & 54.70 \\
\hline $\begin{array}{c}\text { 2, 4-D } \\
\text { @ 20 ppm } \\
\end{array}$ & 66.18 & 76.74 & 73.01 & 71.98 & 66.18 & 74.07 & 73.26 & 71.17 & 66.18 & 75.40 & 73.43 & 71.67 \\
\hline $\begin{array}{c}\text { 2, 4-D } \\
\text { @ } 30 \text { ppm }\end{array}$ & 69.69 & 80.68 & 78.77 & 76.38 & 69.69 & 80.68 & 78.77 & 76.38 & 69.69 & 80.68 & 78.77 & 76.38 \\
\hline $\begin{array}{c}\text { Distilled } \\
\text { water }\end{array}$ & 21.14 & 14.89 & 6.46 & 14.10 & 17.76 & 12.56 & 7.06 & 12.48 & 19.45 & 13.64 & 6.76 & 13.38 \\
\hline Untreated & 21.20 & 14.89 & 6.40 & 14.16 & 17.79 & 12.83 & 6.83 & 12.48 & 19.49 & 13.86 & 6.61 & 13.29 \\
\hline Mean B & 60.46 & 65.07 & 64.21 & 63.25 & 59.22 & 64.17 & 64.96 & 62.78 & 59.87 & 64.62 & 64.58 & - \\
\hline \multicolumn{5}{|c|}{ Factors } & & \multicolumn{3}{|c|}{ S.Em \pm} & \multicolumn{2}{|c|}{ C.D $(1 \%)$} & \multicolumn{2}{|c|}{ C.V } \\
\hline \multicolumn{5}{|c|}{ Female Parents (P) } & & \multicolumn{3}{|c|}{0.35} & \multicolumn{2}{|c|}{ NS } & \multicolumn{2}{|c|}{5.69} \\
\hline \multicolumn{6}{|c|}{ Gametocides with Concentration (T) } & \multicolumn{3}{|c|}{0.84} & \multicolumn{2}{|c|}{2.35} & & \\
\hline \multicolumn{6}{|c|}{ Bud size (B) } & \multicolumn{3}{|c|}{0.43} & \multicolumn{2}{|c|}{1.22} & & \\
\hline \multicolumn{6}{|c|}{$\mathbf{P} \times \mathbf{T}$} & \multicolumn{3}{|c|}{1.18} & \multicolumn{2}{|c|}{4.35} & & \\
\hline \multicolumn{6}{|c|}{$\mathbf{P} \times \mathbf{B}$} & \multicolumn{3}{|c|}{0.62} & \multicolumn{2}{|c|}{2.27} & & \\
\hline \multicolumn{6}{|c|}{ B $\times \mathbf{T}$} & \multicolumn{3}{|c|}{1.45} & \multicolumn{2}{|c|}{4.07} & & \\
\hline \multicolumn{6}{|c|}{$P \times B \times T$} & \multicolumn{3}{|c|}{2.06} & \multicolumn{2}{|c|}{7.54} & & \\
\hline
\end{tabular}

Journal of Experimental Biology and Agriculture Science http://www.jebas.org 
Table 3 Effect of gametocides on inducing pollen sterility (\%) studied under In vitro pollen germination test in okra (A. esculentus L.)

\begin{tabular}{|c|c|c|c|c|c|c|c|c|c|c|c|c|}
\hline \multirow{2}{*}{ Treatment } & \multicolumn{4}{|c|}{ Female Parent 1} & \multicolumn{4}{|c|}{ Female Parent 2} & \multicolumn{3}{|c|}{$\mathbf{T} \times \mathbf{B}$} & \multirow{2}{*}{ Mean } \\
\hline & $\mathbf{B}_{1}$ & $\mathbf{B}_{2}$ & $\mathbf{B}_{3}$ & Mean & $\mathbf{B}_{1}$ & $\mathbf{B}_{2}$ & $\mathbf{B}_{3}$ & Mean & $\mathbf{B}_{1}$ & $\mathbf{B}_{2}$ & $\mathbf{B}_{3}$ & \\
\hline $\begin{array}{c}\text { MH } \\
@ \mathbf{4 0 0} \mathbf{p p m}\end{array}$ & 81.60 & 84.44 & 90.28 & 85.44 & 81.06 & 88.63 & 90.49 & 86.73 & 81.33 & 86.53 & 90.38 & 86.08 \\
\hline $\begin{array}{c}\mathrm{MH} \\
@ \mathbf{4 5 0} \mathrm{ppm} \\
\end{array}$ & 89.66 & 93.32 & 92.46 & 91.81 & 87.85 & 93.48 & 92.75 & 91.36 & 88.75 & 93.40 & 92.60 & 91.59 \\
\hline $\begin{array}{c}\text { MH } \\
@ \mathbf{5 0 0} \mathrm{ppm} \\
\end{array}$ & 88.68 & 91.58 & 91.11 & 90.49 & 88.23 & 90.44 & 91.57 & 90.08 & 88.51 & 91.01 & 91.34 & 90.27 \\
\hline $\begin{array}{cl} & \text { Ethrel } \\
@ 1000 \text { ppm }\end{array}$ & 84.88 & 56.25 & 59.69 & 66.94 & 56.16 & 56.38 & 54.46 & 55.67 & 55.52 & 56.31 & 57.07 & 61.30 \\
\hline $\begin{array}{c}\text { Ethrel } \\
\text { @ } 2000 \text { ppm }\end{array}$ & 57.14 & 71.41 & 73.85 & 67.47 & 66.13 & 71.81 & 64.83 & 67.59 & 61.63 & 71.61 & 69.34 & 67.53 \\
\hline $\begin{array}{c}\text { Ethrel } \\
\text { @ } \mathbf{3 0 0 0} \text { ppm } \\
\end{array}$ & 68.01 & 82.50 & 84.29 & 78.27 & 74.51 & 80.53 & 80.15 & 70.62 & 71.26 & 81.51 & 82.22 & 78.33 \\
\hline $\begin{array}{c}2,4-\mathrm{D} \\
@ 10 \mathrm{ppm}\end{array}$ & 52.96 & 54.17 & 54.74 & 53.96 & 54.99 & 55.80 & 56.37 & 59.05 & 53.97 & 54.99 & 55.55 & 56.50 \\
\hline $\begin{array}{c}\text { 2, 4-D } \\
\text { @ 20 ppm }\end{array}$ & 64.64 & 75.56 & 70.37 & 70.19 & 54.89 & 64.76 & 68.28 & 62.98 & 59.77 & 70.16 & 69.82 & 66.58 \\
\hline $\begin{array}{c}\text { 2, 4-D } \\
\text { @ 30 ppm }\end{array}$ & 68.39 & 80.57 & 79.53 & 76.16 & 68.49 & 76.01 & 72.48 & 72.33 & 68.44 & 78.29 & 76.00 & 74.25 \\
\hline $\begin{array}{c}\text { Distilled } \\
\text { water }\end{array}$ & 14.73 & 9.27 & 6.46 & 10.15 & 14.73 & 9.27 & 6.46 & 10.15 & 14.73 & 9.27 & 6.46 & 10.15 \\
\hline Untreated & 14.17 & 9.44 & 7.11 & 10.24 & 14.86 & 9.36 & 6.24 & 10.15 & 14.51 & 9.40 & 6.67 & 10.19 \\
\hline Mean B & 59.54 & 64.41 & 64.53 & 62.83 & 58.05 & 64.22 & 62.28 & 61.52 & 58.80 & 64.31 & 63.40 & - \\
\hline \multicolumn{5}{|c|}{ Factors } & & \multicolumn{3}{|c|}{ S.Em \pm} & \multicolumn{2}{|c|}{ C.D $(1 \%)$} & \multicolumn{2}{|c|}{ C.V } \\
\hline \multicolumn{6}{|c|}{ Female Parents (P) } & \multicolumn{3}{|c|}{0.44} & \multicolumn{2}{|c|}{ NS } & \multicolumn{2}{|c|}{5.11} \\
\hline \multicolumn{6}{|c|}{ Treatments (T) } & \multicolumn{3}{|c|}{0.99} & \multicolumn{2}{|c|}{2.66} & & \\
\hline \multicolumn{5}{|c|}{ Bud size (B) } & & \multicolumn{3}{|c|}{0.49} & \multicolumn{2}{|c|}{1.39} & & \\
\hline \multicolumn{5}{|c|}{$\mathbf{P} \times \mathbf{T}$} & & \multicolumn{3}{|c|}{1.34} & \multicolumn{2}{|c|}{4.23} & & \\
\hline \multicolumn{5}{|c|}{$P \times B$} & & \multicolumn{3}{|c|}{0.76} & \multicolumn{2}{|c|}{2.24} & & \\
\hline \multicolumn{5}{|c|}{ B $\times \mathbf{T}$} & & \multicolumn{3}{|c|}{1.71} & \multicolumn{2}{|c|}{4.60} & & \\
\hline \multicolumn{5}{|c|}{$P \times B \times T$} & & \multicolumn{3}{|c|}{2.42} & \multicolumn{2}{|c|}{7.87} & & \\
\hline
\end{tabular}

Legend of this table is similar to the table 2

way treatment combinations, buds of $45 \mathrm{~mm}$ size treated with MH @ 500 ppm recorded higher pollen sterility (91.18\%), which is not showing any significant different with $450 \mathrm{ppm}(90.77 \%)$ followed by ethrel @ 3000 ppm $(78.33 \%)$ and least was recorded in untreated control $(6.61 \%)$.

The results were confirmed from in vitro pollen germination test. Maximum pollen sterility was obtained in MH treatment (89.31 $\%)$ and this was followed by ethrel $(69.05 \%)$ and 2, 4-D (65.44 $\%)$. Lower pollen sterility was recorded in untreated control $(10.19 \%)$ and this was at par with distilled water $(10.15 \%)$. Result of study revealed that increasing the concentration of gametocides increases the pollen sterility. Findings of this study are in agreement with the findings of Dubey \& Singh (1967) and Deepak et al. (2007) who reported higher pollen sterility at higher concentration of $\mathrm{MH}$.

The flower buds treated with MH (450 ppm) has shown higher pollen sterility (91.59\%) but this was not statistically different from the MH (500 ppm) (90.27\%). Further, among the different flower bud size, $45 \mathrm{~mm}$ recorded higher pollen sterility $(64.31 \%$ ,) which is at par with $50 \mathrm{~mm}$ bud size $(63.40 \%)$. In two way treatment combinations, buds of 45 mm size treated with MH @ $450 \mathrm{ppm}$ recorded higher pollen sterility $(93.40 \%)$, followed by ethrel @ 3000 ppm (82.22\%) and least was recorded in distilled water spray $(6.46 \%)$. 
Artificial induction of pollen sterility with the application of $\mathrm{MH}$ may cause abnormalities like shrivelling of microspores or premature disintegration of tapetum starved microspore which leads to death of the pollen (Deepak et al., 2007). Shrinkage of microspores perhaps associated with the shrinkage of cytoplasm when anther treated with $\mathrm{MH}$ in Capsicum annum, which might led to pollen sterility (Chauhan, 1980). Malic hydrazide also induced maximum pollen sterility in several crops like okra (Dubey \& Singh, 1967; Verma \& Singh 1978), brinjal (Echlin, 1971; Sreenivasa, 2001), chilli (Chauhan, 1980) and niger (Swarnalatha, 2005). Being a pyridazine compound, MH is known as a clastogenic agent in plants and is known to inhibit the synthesis of nucleic acids and proteins. The application of $\mathrm{MH}$ in Vicia faba was reported to induce chromosome aberrations and sister chromatid exchanges in the root meristems (Rizal et al., 2015). Ethrel also induced higher level of pollen sterility when treated at bolting stage in lettuce (Han \& Lee, 1972) and egg plant (Dikii \& Anikeenko, 1975; Helal \& El-Saied Zaki, 1981). In conclusion, it was evident that, $\mathrm{MH}$ (450 ppm) sprayed on $45 \mathrm{~mm}$ bud size stage found to be most ideal for inducing maximum pollen sterility in okra to skip emasculation process during hybrid seed production.

\section{Conflict of Interest}

Authors would hereby like to declare that there is no conflict of interests that could possibly arise.

\section{References}

Chauhan SVS (1980) Effect of maleic hydrazide, FW-450 and dalapon on another development in Capsicum annuum. Journal of Indian Botanical Society 59: 133-136.

Dafni A, Firmage D (2000) Pollen viability and longevity: practical, ecological and evolutionary implications. Plant Systematics and Evolution 222: 113-132

Davaluri V (2015) Child and Adult Labour in Vegetable Seed Production in India. In: Soiled seeds, India Committee of Netherlands Pp: 19-26. Available on http://www.indianet.nl/pdf/SoiledSeeds.pdf access on 29th April, 1979.

Deepak KD, Deshpande Vyakarnahal BS, Ravikumar RL, Uppar DS, Hosamani RM (2007) Chemical induction of male sterility and histological studies in Okra (Abelmoschus esculentus (L.) Monech.). Karnataka Journal Agricultural Sciences 21: 202-205.

Dikii SP, Anikeenko VS (1975) The induction of male sterility in eggplant and pepper. Ref. Zh., 3.55 .202 (vide Plant Breed. Abstr., 47: 156, 1725).
Dubey RS, Singh SP (1967) Chemical induction of male sterility in Abelmoschous esculentus (L) Moench. Indian Journal of Agricultural Sciences 38 : 108-114

Echlin P (1971) The role of tapetum during microsporogenesis of angiosperms, in Pollen Development and Physiology. In: HeslopHarrison (Ed.), Butterowrths, London, Pp.41-61.

Gaaliche B, Majdoub A, Trad M, Mars M (2013) Assessment of Pollen Viability, Germination, and Tube Growth in Eight Tunisian Caprifig (Ficus carica L.) Cultivars. ISRN Agronomy 2013: 1-4. DOI: http://dx.doi.org/10.1155/2013/207434.

Han DW, JJ Lee (1972) Effect of ethrel, RH 531 and gibberellin on the sterile pollen induction in lettuce, Thesis Seoul Municipal College of Agricultural (C.f. Plant Breed. Absts. 1974, Absts. 4774).

Helal RM, El-Saied Zaki M (1981) Effect of 2, 4-D and ethephon foliar sprays on induction of pollen sterility in egg plant. Egyptian Journal of Horticulture 8: 101-108.

Van der Meer QP, Van Bennekom JL (1973) Gibberellic acid as a gametocide for the common onion (Allium cepa L.). Euphytica 22: 239--243.

Prakash M, Veeramani B, Kannan K, Vasline YA, Ganesan J (2001) Effect of 2,4-D and ethrel on induction of pollen sterility in Sesame. Sesame and Safflower Newsletter, No. 16.

Rizal G, Karki S, Garcia R, Larazo N, Alcasid M, Quick WP (2015) The use of Maleic Hydrazide for effective hybridization of Setaria viridis. PLoS One $\mathbf{1 0}$ : 1-12. DOI: doi: 10.1371/journal.pone.0125092.

Rehm S (1952) Male sterile plants by chemical treatments. Nature 170: $38-39$.

Salgare SA (1995) Gametocidal effect of acrolein on ornamental chillies. Flora and Fauna, Jhansi 1: 95-98.

Sharma Y, Sharma SN (2005) Chemical hybridizing agents (CHA)-A tool for hybrid seed production- A review. Agriculture Reviews 26: 114-123.

Sreenivasa VC (2001) Physiological and Histochemical changes associated with the male sterility in brinjal using plant growth regulators. M.Sc. (Agri) Thesis submitted to the University of Agricultural Sciences, Dharwad (India).

Swarnalatha V (2005) Induction of male sterility and histological studies on induced male sterility in niger (Guizotia abyssinica 
Cass). M.Sc.(Agri.) Thesis submitted to the University of Agricultural Sciences, Dharwad (India).

Verma RB, Singh GN (1978) Studies on chemical induction of male sterility in bhendi (Abelmoschus esculentus Moech). Indian Journal of Agricultural Research 12: 22-24.
Yoneyama M, Kitayama T, Taniura H, Yoneda Y (2003). Immersion fixation with Carnoy solution for conventional immunohistochemical detection of particular N-methyl-Daspartate receptor subunits in murine hippocampus". Journal of Neuro Science Research 73 : 416-26. 